\title{
RELIGIÃO, RELIGIOSIDADE OU ESPIRITUALIDADE? A IMPORTÂNCIA DA DEFINIÇÃO DOS TERMOS NO CONTEXTO DE SAÚDE FISICA E PSIQUICA
}

\author{
CHAVES, F.S. \\ Faculdade Unida de Vitória - Rua Engenheiro Fábio Ruschi, n 161 - Bento Ferreira - Vitória/ES - \\ CEP: 29.050-670.
}

Estabelecer uma possível relação entre saúde e espiritualidade bem como a sua relevância no mundo moderno passa pelo caminho das definições dos termos. Isto é importante porque dependendo do termo utilizado a espiritualidade se apresenta como opressora e não libertadora, desenvolve mais patologias do que promove a cura. Autores como Paiva, ao falar sobre Psicologia e Espiritualidade, apresenta as formas como a espiritualidade era considerada e como ela se apresenta na contemporaneidade, focando a espiritualidade humanista como a mais utilizada hoje abarcando até a espiritualidade ateia. Assim sendo, o objetivo aqui proposto é fazer as devidas diferenciações conceituais entre os termos Religião, Religiosidade e Espiritualidade para então focar em que sentido os termos se apresentam como coadjuvantes no contexto de saúde física e psíquica. A metodologia utilizada para a construção deste trabalho foi a Revisão Bibliográfica de Literatura, a partir de livros e artigos que trouxessem maiores esclarecimentos sobre o tema abordado. Os resultados apontam que há diferenciações nos termos Religião, Religiosidade e Espiritualidade e que tais diferenciações influenciam no contexto de saúde física e psíquica do indivíduo. Enquanto a religião e religiosidade estão ligadas aos aspectos institucionais, a espiritualidade está vinculada ao sentido e propósito da vida. Com isto, o conceito de espiritualidade coaduna com a proposta do novo modelo médico - o paradigma da integralidade. Conclui-se, a partir dos autores como Paiva, Rhutes, Vieira e Rosa que a definição contemporânea sobre Religião/Religiosidade/Espiritualidade se volta mais para a vivência da religião do que para os seus aspectos institucionais, indicando que a espiritualidade não institucional, não presa às amarras das tradições religiosas poderá ser benéfica tanto para o físico quanto para a psique humana, o que poderá contribuir para o processo de humanização do individuo.

Palavras Chaves: religião, religiosidade e espiritualidade, saúde física e psíquica, novo modelo médico. Financiamento: FABERJ (Faculdade Batista do Estado do Rio de Janeiro).

\section{REFERÊNCIAS}

PAIVA. José Geraldo de. Psicologia e espiritualidade. IV Congresso de Psicologia da Unifil. Disponível em: $<$ http://www.unifil.br/portal/arquivos/publicacoes/paginas/2011/6/331_355_publipg.pdf>

VIEIRA, Carlos Alberto Pinheiro. A proposta de Gianni Vattimo para uma espiritualidade pós-metafisica. PARALELLUS, Recife, Ano 3, n. 6, jul./dez. 2012, p. 189-204. ISSN: 2178-8162.

ROSA, Wanderley Pereira da. Kênosis e espiritualidade: uma leitura a partir do pensamento pós-metafísico de Gianni Vattimo. In: ROCHA, Abdruschin Schaeffer et al. Espiritualidades contemporâneas. Vitória - ES: Editora Unida: Faculdade Unida de Vitória, 2013.

RUTHES, Vanessa Roberta Massambani. A relação entre espiritualidade e saúde: um novo paradigma. Saberes em Ação. Ano 02, Nº3, Jan/Jun 2014. 